\title{
Looking Over the Cliff: Globalizing Inequalities and the Challenge for a Global Social Theory
}

\author{
Jason Powell
}

\section{Introduction}

Every nation-state across all corners of the globe has been experiencing the most formidable structural, economic climate since the 1930s. One of the central causes of global financial instability has been transnational financial institutions and lack of regulation for consumer populations in different nation-states. It is not just financial institutions but also nation-states. For example, in May 2010, the Greek government has turned to Europe to help stimulate its economy (with 100 billion euros loan); otherwise, Greece would be at risk for bankruptcy which would then have ripple effects for other EU economies linked through economic harmonization, such as EU country memberships of the Euro - which would dramatically lose its value in the global economic market if the Greek economy was not propelled by support from other EU countries. President Obama has recognized the potential instability that Greece could potentially have on the US economy; and hence, this raises questions about the wider global economy. Whilst these problems require a global response by the international community and political leaders, they also require a response and engagement by social scientists. Historically, there have been a number of social scientists who explored how the Enlightenment and its legacy have impinged upon the emergence and creation of and social science disciplines that have attempted to explain social, economic, political, and cultural transformations in modernity (Layder 2006).

The processes of globalization in the 21 st century are not associated with encompassing ideologies in the way that was the case with processes focused at level of the nation-state. The world is changing at a rapid pace, and the scope and impact of change have multiple dimensions and implications that transcend geographic and cultural boundaries (Bauman 1998). Hence, globalization has transformed the way people see themselves in the world. Everyone must now reflexively respond to the common predicament of living in one world. This provokes the formulation of contending world views. In a compressed world, the comparison and confrontation of world views are bound to produce new cultural conflict. In such conflict, old traditions and new ideas play a key symbolic role, since they can be mobilized to provide an ultimate justification for one's view of the world - a case in point being the resurgence of Islamic fundamentalist groups that combine traditionalism with a global agenda but also the response of US/UK governments that wished to promote 'democracy' and 'freedom' through a 'War on Terror' against such groups (Sands 2006). A globalized world is thus integrated but not harmonious, a single place but diverse, a construct of consciousness but prone to multiplicity and fragmentation. In that context, it is highly pertinent that critical social science steps up to the challenge and rethinks how we 'unmask' the implications of globalization and impact on modern society.

\section{The Power of Globalization}

Globalization has become one of the central but contested concepts of contemporary social science (Ritzer 
2004). The term has further entered everyday commentary and analysis and features in many political, cultural, and economic debates. The contemporary globalized world order originates in the international organizations and regulatory systems set up after World War II - including the United Nations, General Agreement on Tariffs and Trade (now the World Trade Organization), the International Monetary Fund, and the World Bank (Bauman 1998). However, the end of the Cold War was the prelude to the maturity of the concept of globalization. From 1989 to the present, it is possible at least to imagine a 'borderless' world (Ohmae 1990) in which people, goods, ideas, and images would flow with relative ease, and the major global division between East and West had gone. A world divided by competing ideologies of capitalism and state socialism has given way to a more uncertain world in which capitalism has become the dominant economic and social system, even for the communist-led People's Republic of China. Coinciding with these changes, a major impetus to globalization was the development and availability of digital communication technologies from the late-1980s with dramatic consequences for the way economic and personal behavior were conducted - this has transcended to mass communication from the Internet in the 1990s to Mobile Phones from 2000 onwards (McGrew 2007). The collapse of communism in Eastern Europe and the USSR, and its modernizing in China, plus growth of digital technologies further coincided with a global restructuring of the state, finance, production, and consumption associated with neo-liberalism. Coupled with this, in a post 9/11 world, there has been the recent 'War on Terror' and its implications for the reordering of the geo-political global agenda.

Since the advent of industrial capitalism as a feature of development of modernity, intellectual discourse has been replete with allusions to phenomena strikingly akin to those that have garnered the attention of recent theorists of globalization (Bauman 2001). Nineteenth- and twentieth-century philosophy and social commentary include numerous references to an inchoate yet widely shared awareness that experiences of distance and space are inevitably transformed by the emergence of high-speed forms of technological transportation (for example, rail and air travel) and communication (the telephone) that dramatically heighten possibilities for human interaction across existing geographical and political divides (Smart 2007). Bauman has proposed nothing less than a rewriting of human history based on what he called 'the retrospective discovery' of the centrality of spatial distance and speed of communication in the constitution of all societies (Bauman 1998:15).

However, because they were rooted in its core relations, private property and wage labor, they would keep 'reasserting themselves', and on an ever greater scale, so long as those relations were reproduced over time. The consequence is that globalization as a spatial process that has facilitated the emergence of a new kind of global city based on highly specialized service economies that serve specific, particularized functions in the global economic system at the expense of former logics of organization tied to manufacturing-based economies. To enable global markets to function effectively, they need to be underpinned by local managerial work that is concentrated in cities. Further, privatization and deregulation during the 1980s and 1990s shifted various governance functions to the corporate world, again centralizing these activities in urban spaces. In post-industrial cities there is a concentration of command functions that serve as production sites for finance and the other leading industries and provide marketplaces where firms and governments can buy financial instruments and services. Global cities become strategic sites for the acceleration of capital and information flows, and at the same time spaces of increasing socioeconomic polarization.

One effect of this process has been that such cities have gained in importance and power relative to nation-states. There have emerged new 'corridors' and zones around nodal cities with increasingly relative independence from surrounding areas. Globalization simultaneously brings home and exports the processes of privatization, competition, rationalization, and deregulation as well as the transformation of all sectors of society through technology and the flexibilization and deregulation of employment. As a process, debate centers on the uses of globalization as the rationale and means by which corporate capital may transnationally pursue new low wage strategies and weaken the power of labour, women, and ethnic minority populations.

But whether globalization is imagined or real requires rigorous analysis. The next section attempts to pull together main authors, ideas and trajectories of globalization and illustrate it by using key examples to consolidate understanding.

\section{Contested Complexities of Globalization and Neo-Liberalism}

The theorization of globalization is extremely complex. Roland Robertson refers to the concept of 'global 
consciousness', which refers to 'the compression of the world and the intensification of consciousness of the world as a whole' (1992:8). Through thought and action, global consciousness makes the world a single place. What it means to live in this place, and how it must be ordered, become universal questions. However, European expansion and state formation have boosted globalization since the seventeenth century and the contemporary shape of the world in the nineteenth century, when international communications, transportation, and conflict dramatically intensified relationships across societal boundaries (Mann 2006). In that period, the main reference points of fully globalized order took shape: nation-state, individual self, world-system, societies, and one humanity. These elements of the global situation became 'relativized' since national societies and individuals, in particular, must interpret their very existence as parts of a larger whole. To some extent, a common framework has guided that interpretive work; for example, states can appeal to a universal doctrine of nationalism to legitimate their particularizing claims to sovereignty and cultural distinction (Delanty and Isin 2003). But such limited common principles do not provide a basis for world order.

For Anthony Giddens (1991) the concept of time-space distantiation is central. This is a process in which locales are shaped by events far away and vice versa, while social relations are disembedded, or 'lifted out' from locales. For example, peasant households in traditional societies largely produced their own means of subsistence, a tithe was often paid in kind (goods, animals, or labor), money was of limited value, and economic exchange was local and particularistic. 'Reflexive modernization' replaced local exchange with universal exchange of money, which simplifies otherwise impossibly complex transitions and enables the circulation of highly complex forms of information and value in increasingly abstract and symbolic forms. The exchange of money establishes social relations across time and space, which under globalization is speeded up. Similarly, expert cultures arise as a result of the scientific revolutions, which bring an increase in technical knowledge and specialization. Specialists claim 'universal' and scientific forms of knowledge, which enable the establishment of social relations across vast expanses of time and space. Social distance is created between professionals and their clients as in the modern medical model, which is based upon the universal claims of science. As expert knowledge dominates across the globe, local perspectives become devalued and modern societies are reliant on "risk" and "expert systems" (Beck 1992). Trust is increasingly the key to the relationship between the individual and expert systems and is the glue that holds modern societies together. But where trust is undermined, individuals experience 'ontological insecurity' and a sense of insecurity with regard to their social reality (Giddens 1991).

The Internet itself has changed not only the way business works but also the way people interact on a personal level - from buying and selling online to planning for retirement, managing investment and online bank accounts. Although, in recent times, the dark side of the Internet has revealed illegitimate ways that groups and individuals use 'hyper borderless worlds' with data espionage, data theft, credit card fraud, child pornography, extremism and terrorism - are ever more common on the Internet with up to $£ 40$ billion a year made by international organized crime syndicates on the web (Powell 2006). The Internet is a global system and decisions made on virtual 'platforms' (that are created by corporations rather than governments) determine how money moves around the globe. The emergence of 'around-the-world' 24/7 financial markets, where major cross-border financial transactions are made in cyberspace represents a familiar example of the economic face of globalization (Schneider 2007). The definition and social construction of 'the problem' of state power is transferring from the state and its citizenry to private sector global finance. For example, Powell (2006) points to how the economic stakes and social consequences of 'ageing populations' cannot be underestimated for the upholding of power by multi-national corporations. Looking ahead, the race is on for 'Global Custody' through the socially constructed 'Ticking of the Pensions Time Bomb', as described by the Financial Times with Europe as a 'battleground' for the US Banks (The Bank of New York, State Street Bank, JP Morgan and Citibank) competing against the European Deutsche, BNP Paribas and HSBC for custody of the growing pensions market and the highly lucrative financial services supporting it. As further incentive to eager financial enterprises, the 'global picture' in private wealth drawn from the lucrative business of pension providing is estimated by 2007 to exceed $\$ 13,000$ billion in the USA, $\$ 10,000$ billion in Europe, and $\$ 7,200$ billion in Asia. In less developed countries, women especially have been among those most affected by the privatization of pensions and health care, and the burden of debt repayments to agencies such as the World Bank and the IMF (Walker and Naegelhe 1999).

Indeed, Thrift (1994) suggests that international systems reliant upon rapid electronic communication and diffusion of data do not always result in a lessening of the importance of individual actors or localized face-toface micro-social relations. He acknowledges that the international financial system has become, to an extent, 'disembedded from place', but emphasizes that transnational financial networks generate vast amounts of data and 
a range of 'meanings' pertaining to the interpretation of those data. The result is that inter-personal exchanges involving individual agency to negotiate, discuss, interpret, and act upon the data are still of considerable importance. Since the vast majority of human activities is still tied to a concrete geographical location, the more decisive facet of globalization concerns the manner in which distant events and forces impact on the local or 'glocal' situation (Tomlinson 1999:9).

John Urry (2005) argues that the changes associated with globalization are so far-reaching that we should now talk of a 'theory beyond societies'. This position is informed by the alleged decline of the nation-state in a globalized world, which has led to wider questioning of the idea of 'society' as a territorially bounded entity. This in turn prepares the ground for claims to the effect that since 'society' was a core theoretical concept, the very foundations of social science discipline have likewise been undermined. The central concepts of the new socialities are space (social topologies), regions (interregional competition), networks (new social morphology), and fluids (global enterprises). Mobility is central to this thesis since globalization is the complex movement of people, images, goods, finances, and so on that constitutes a process across regions in faster and unpredictable shapes, all with no clear point of arrival or departure.

Despite the contrasting theoretical understandings of globalization, there is some measure of agreement that it creates new opportunities or threats. For example, globalization offers new forms of cosmopolitanism (Delanty 2006) and economic growth (Smart 2007) but also new threats and global risks such as ecological crises of global warming, climate change and environmental pollution; global health pandemics such as 'swine flu'; and international crime and terrorism. Globalization may be seen as encroachment and colonization as global corporations and technologies erode local customs and ways of life, which in turn engenders new forms of protest. Giddens has argued that the effects of globalization must also be seen as positive and that integration into the global economy increases economic activity and raises living standards. For example, Legrain (2006) claims that in 2000 the per capita income of citizens was four times greater than that in 1950. Between 1870 and 1979, production per worker became 26 times greater in Japan and 22 times greater in Sweden. In the whole world in 2000 it was double what it was in 1962. Even more significantly, Legrain (2006) argues that those nation-states isolated from the global capitalist economy have done less well than those that have engaged with it. Poor countries that are open to international trade grew over six times faster in the 1970s and 1980s than those that shut themselves off from it: 4.5 percent a year, rather than 0.7 percent.

By contrast to Legrain's (2006) idealism, it can be argued that global patterns of inequality have become increasingly polarized (Estes, Biggs, and Phillipson 2003). According to the United Nations, the richest 20 percent in the world 'own' 80 percent of the wealth; the second 20 percent own 10 percent; the third 20 percent own 6 percent; the fourth 20 percent own 3 percent; and the poorest 20 percent own only 1 percent. Throughout the world, 2.7 billion people live on less than $\$ 2$ per day. These global inequalities predate globalization, of course, but there are global processes that are maintaining a highly unequal social system (Phillipson 2005). Contradictions in global society are illustrated in other ways, too. The globalization of capital may not have driven costs down in developed countries where few workers are prepared to tolerate the conditions this new model creates. Flexible global ordering systems need not just produce flexible labor, but flexible labor in excess, because to manage the supply of labor it is necessary to have a surplus. Migrants have met this need (Miles 2004). But in the wake of hostility manifest in many developed countries, especially following threats of terrorist attack in the United States and Europe migrants face tightening border controls and deportation of those who are not in areas where there is a shortage of skills.

President Obama currently sort to transform the provision of health care in the US, but the vested interests of the privatized health care system are seeking to limit and oppose the main thrust of his proposals, presenting these as being 'socialist' extensions of state power. Paradoxically, however, the neo-liberal ideology of globalization further bolsters the more restrictive limitations on the role of the state with respect to its citizens. David Held and his colleagues make the point that a distinctive feature of the present period is the extent to which:

financial globalization has imposed an external financial discipline on governments that has contributed to both the emergence of a more market-friendly state and a shift in the balance of power between the state and financial markets.

(Held 2000:232)

In this respect, the political agenda of advanced capitalist states reflects in part the constraints of global finance, even though the specific impact of financial globalization will vary greatly among states. A tangible consequence is the insertion of the operatives and 'requisites' of global finance into state policy-making in ways that frame, if not dictate, the parameters of state power. 
These developments can be viewed as part of a new global process of shaping the lives of present and future generations of populations in western and non-western states. The change has been variously analyzed as a move from 'organized' to 'disorganised capitalism', to a shift from 'simple' to 'reflexive modernity', and to the transformation from 'Fordist' to 'post-Fordist economies'. The final part of this paper looks ahead and provides some reflective thoughts for questioning the extent to which a 'global social theory' is warranted.

\section{| The Future of a Global Social Theory?}

At this point in the twenty-first century, an array of opportunities and challenges present themselves for the study of social theory. There is a need to develop a clearer perspective on the pressures facing social groups that impinge on 'race', class, age, gender, disability, and sexuality as a result of global change. A significant issue is how globalization and its impingement on local governance is transforming the everyday texture of day-to-day living. In this context, the need for a framework to respond to the challenge associated with globalization is warranted. The key dimensions here are the changing and contested form of the nation-state, citizenship and nationalism; the enhanced role of supra-national bodies; the increased power of multi-national corporations; and emergence and retrenching of social inequalities across the globe.

I argue that social theory should not merely provide 'critical questions' about dynamics of social relations, but rather, it is what one does with critical questions that is the cornerstone for critical theorizing.

A key aim of social theory is, first, the examination of the social construction of reality and critical debunking of such contingent realities. A central task for social theory concerns the need to examine the structural inequalities and power dynamics that perpetuate current understandings of the social world. An analysis that accepts Enlightenment assumptions about, for example, 'equality', fails to ask the key questions about why this state of affairs holds true for some rather than for others. A critical social theory must move beyond appearances and seek explanations that overturn conformist realities. Crucially, power relations, social processes and structures must be examined as they appear in everyday relations. Links must be made between the traditional and contemporary social theories between macro, micro and meso levels of analysis, so that the pull of social inequalities can be identified and the emotional experience and daily interpretation of them explored.

A key issue in theoretical interpretation concerns the place and nature of 'society'. The ideas of society as a bounded self-sufficient entity most associated with the recent neo-functionalism of Alexander (2004) had become taken for granted within mainstream theorizing. Such a formulation assumes there is a coherent and bounded society into which social integration is attainable. This view has become prominent by a small group of western societies, especially those associated with recent 'War on Terror' who aggressively promote nation statehood and democratic freedom (Walklate and Mythen 2007). Nevertheless, the notion of society as a sovereign entity is changing profoundly with the intensifying social forces of globalization:

there are exceptional levels of global interdependence, unpredictable shock waves spill out 'chaotically' from one part to the system as a whole; there are not just societies but massively powerful empires roaming around the globe; and there is a mass mobility of people, objects and dangerous human wastes.

(Urry 2000:13)

This critical questioning of the modernist basis to society is a challenging one to social theory. In a sense the traditional formulation of 'society' is being challenged from global forces that impinges on new technology that transforms the experience of social relations. Indeed, in a networked world, everyday life is becoming detached from the protective nation-state seen to be at the core of occidental modernity. Steering a path between Giddens's (1991) 'global optimists' and 'global pessimists', it may be suggested that a new formulation is required that recognizes diverse and unequal networks in and through the way people interact throughout their lives across national, transnational, and sub-cultural contexts. A major dimension of inequities impinges on debates on issues such as climate change, power of multinational corporations, and third-world countries of debt repayment. The phenomenon of globalization has transformed debates within social theory to the extent that it has reordered concepts typically used by social theorists across micro-macro continuum (Bauman 1998). Ideas associated with the idea of modernity, the state, gender, class relations, ageing, and ethnicity have retained their importance but their collective and individualized meaning is different and fragmented in the context of the influence of global actors and institutions (Powell, 2006). 
A contentious point is that accepting the importance of globalization also strengthens the case for rethinking social theory through reassertion of macro analysis. Given the explanatory role of social theory, globalization is setting major new challenges in terms of interaction between individuals, communities, and nation states and the global structure within which these are constructed, contested and nested. Analyzing the interpretation of daily life may be more appropriately assessed in the contexts of networks and flows characteristic of global society, these producing a loosening in those attachments which have traditionally embedded people to locative settings: for Marxists in social class and for Feminists in gendered configurations. With globalization, these attachments are maintained but recontextualized and reembedded with the influence of transnational communities, corporations and international governmental organizations producing new agendas and challenges for how we understand 'modern society' (Turner 2006). Further, the nature of 'citizenship' and 'rights' so heavily influenced by Enlightenment philosophy are both heavily contested under the lead of the complex and commanding influences of powerful non-democratic intergovernmental structures such as the World Bank and International Monatory Fund (IMF), private multinational corporations such as banks and western states that are under new pressures associated with accelerating demography and migration. This contrasts sharply with the Enlightenment period which saw rights arguably independently defined and negotiated through various manifestations of British, European and American nation-building and sovereign state-based power.

It may also be suggested that democratic rights have become more fragmented as well as individualized. What has changed is the duty and necessity to cope with these risks that are being increasingly transferred to families (Bauman 2000). The new social construction of everyday life may be defined as a global problem and issue but the social reconstruction of how experience globalization is being cast as a personal rather than a collective responsibility. This development also implies an important role for social theory in interconnecting macro and micro perspectives with new approaches in order to understand how global processes contribute to the reshaping of the institutions in which the experiences of social groups are embedded.

A further task must be to construct new social theories about the nature of individualization in light of more fluid borders surrounding nation-states. Important questions concern whether and how people, socially differentiated, are facilitated or constrained by the spread of mobile communities along with more varied forms of belonging and citizenship. Social theory will be profoundly influenced by the 'development of a common consciousness of human society on a world scale and an increased awareness of the totality of human social relations as the largest constitutive framework of all relations' (Shaw 2002:12).

A further issue concerns the extent to which social theory may challenge the dominant institutions that reproduce and perpetuate social divisions in society. Applications of the policy sciences take for granted existing systems of capitalism as scholars work largely within 'definitions of the situation' that are framed by classical economic theories, assumptions and models of cost-effectiveness and individual level outcomes. The end result is that only a limited array of potentially viable policy options assuring the serious consideration of only incremental changes that will do little to alter the underlying structural economic problems facing social groups such as, for example, older people (Powell 2006).

In challenging this, there is a need for theorizing that examines the structural forces and social processes that profoundly shape individual and group experience in the global community of the first, second and third worlds. Theoretical development from a critical perspective seeks to illuminate alternative understandings and a vision to 'what is possible'. It is a requisite to lifting the ideological veil of scientific objectivity that obscures and mystifies inequality and social injustice in a society and economy that prioritizes the production of goods and services primarily for its economic and exchange value rather than for its social value and capacity to meet human needs across the world.

\section{| References}

Bauman, Z. 1998. Globalization: The Human Consequences. Cambridge: Polity Press.

Borja, J. and M. Castells. 1997. Local and Global: Management of Cities in the Information Age. London: Earthscan.
Carey, G. and J. Wolfensohn. 1999. "Creditors of the Poor - Yes, All of Us, Comment and Analysis." The Guardian June 15th. 
Coffey, W.J. 1996. “The 'Newer' International Division of Labour.” In The Global Economy in Transition, edited by P.W. Daniels, W.F. Lever, and Addison

Wesley. Essex: Longman and Harlow.

Dawkins, W. 1997. "Sense of Unease Over a Britain Out in the Cold: Toyota Does Not Speak For All But There is Vague Concern in Japan." Financial Times, January 31 st.

Delanty, G. and E. Isin, eds. 2003. Handbook of Historical Sociology. London: Sage.

Denny, C. and L. Elliott. 1999. "Fears of Big Talk But Little Money.” The Guardian, June 14th, p. 11.

Dicken, P. 1993. 'The Growth Economies of Pacific Asia in Their Changing Global Context." Pp. 22-42 (Ch. 2) in Economic and Social Development in Pacific Asia, edited by C. Dixon and Drakakis-Smith. London: Routledge.

----. 1998. Global Shift: Transforming the World Economy. 3d ed. London: Paul Chapman.

Estes, C.L., S. Biggs, and C. Phillipson. 2003. Social Theory, Social Policy and Ageing: A Critical Introduction. Maidenhead: Open University.

Finance and Development. 1992. "Recent Trends in FDI for the Developing World.” 29: 50-51.

Giddens, A. 1998. The Third Way: The Renewal of Social Democracy. Cambridge: Polity Press.

Gifford, S. 1994. Japan Among the Powers 1890-1990. London: New Haven University Press.

Hutton, W. 1996. The State We're In. Rev. ed. London: Vintage.

Jilberto, A.E.F. and A. Mommen. 1998. "Globalization Versus Regionalization.” Pp. 1-26 (Ch. 1) in Regionalization and Globalization in the Modern World Economy: Perspectives on the Third World and Transitional Economies, edited by A.E.F. Jilberto and A. Mommen. London: Routledge.

Khong, Cho-Oon. 1996. "Pacific Asia as a Region: the View from Business."

Pp. 167-180 (Ch. 7) in Fragmented Asia: Regional Integration and National Disintegration, edited by I.G. Cook, M.A. Doel, and R. Li. Avebury: Aldershot.

Lee, B.T and T.S. Bahrin. 1998. "Wither the Borders? Towards a New Dimension of Geographical Differentiation.” Pp. 3-13 (Ch. 1) in Vanishing Borders: The New International Order of the 21 st Century, edited by B.T. Lee and T.S. Bahrin. Ashgate: Aldershot.
Lee, S. 1998. "Managed or Mismanaged Trade? US-Japan Trade Relations During the Clinton Presidency." Pp. 209-233 (Ch. 7) in Dynamic Asia: Business, Trade and Economic Development in Pacific Asia, edited by I.G. Cook, M.A. Doel, R. Li, and Y. Wang. Ashgate: Aldershot.

Liu, Fu-Kuo. 1996. "Industrial Development and the Impetus to Regional Economic Integration in Pacific Asia.” Pp. 137-166 (Ch.6) in Fragmented Asia: Regional Integration and National Disintegration in Pacific Asia, edited by I.G. Cook, M.A. Doel, and R. Li. Avebury: Aldershot.

Martin, H.P and H. Schumann. 1997. The Global Trap: Globalization and the Assault on Prosperity and Democracy. London: Zed.

Martin, R. and R. Rowthorn, eds. 1986. The Geography of Deindustrialization. London: Macmillan.

Nsouli, S.M. 1999. "A Decade of Transition: An Overview of the Achievements and Challenges." Finance and Development $36(2): 2-5$

Ohmae, K. 1990. The Borderless World: Power and Strategy in the Interlinked Economy. London: Harper Collins.

Ouattara, A.D. 1999. "Africa: An Agenda for the 21st Century." Finance and Development 36(1): 2-5.

Postel-Vinay, K. 1996. "Local Actors and International Regionalism: the Case of the Sea of Japan Zone." The Pacific Review 9: 489-503.

Powell, J.L. 2006. Social Theory and Aging. Lanham: Rowman and Littlefield.

Pyle, K.B. 1996. The Making of Modern Japan. 2d ed. Lexington, Mass.: D.C. Heath and Company.

Robertson, D. 1997. "Introduction: East Asian Trade and the New World Trade Order." Pp. 1-17 in East Asian Trade After the Uruguay Round, edited by D. Robertson. Cambridge: Cambridge University Press.

Rozman, G. 1998. "Flawed Regionalism: Reconceptualizing Northeast Asia in the 1990s." The Pacific Review 11:1-27.

Samuelson, R.J. 1999. "Spotlight: The Troubled World Economy." Brittanica Book of the Year: Events of 1998. Chicago: Encyclopaedia Britannica, 450.

Simmons, I.G. 1996. Changing the Face of the Earth: Culture, Environment, History. 2d ed. Oxford: Blackwell.

Soros, G. 1998. The Crisis of Global Capitalism: Open Society Endangered. London: Little, Brown and Company. 
